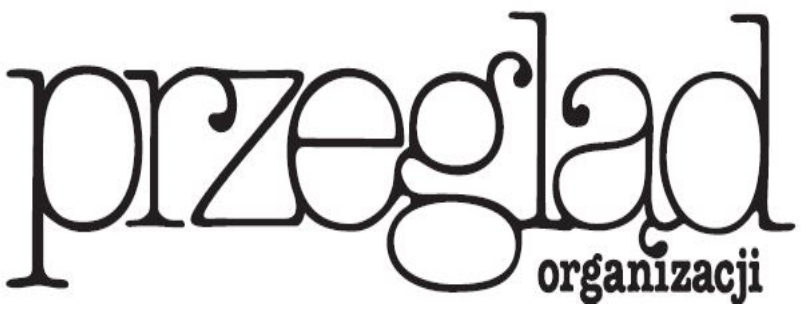

Miesięcznik TNOiK

Założył Karol Adamiecki w 1926 r.

\title{
WYKORZYSTANIE KOMPETENCJI \\ W PROCESIE ZARZADZANIA ZASOBAMI LUDZKIMI W SIŁACH ZBROJNYCH RP
}

https://doi.org/10.33141/po.2019.02.05

\section{Maria Jabłońska-Wołoszyn}

\section{Wprowadzenie}

$\mathbf{Z}$ ainteresowanie w wojsku podejściem opartym na kompetencjach można odnieść do doświadczeń organizacji biznesowych, gdzie wykorzystanie kompetencji jest przejawem dbałości organizacji o zwiększanie swojej konkurencyjności (Dubois, Rothwell, 2008, s. 40). Większość praktyków wiąże je z rezultatami organizacyjnymi, traktując opracowanie i wdrożenie rozwiązań kompetencyjnych jako jedną z najważniejszych inicjatyw strategicznych przedsiębiorstwa (Sienkiewicz, 2013, s. 68-71). Zgodnie z definicją modelu kompetencji, odzwierciedla on specyfikę strategii, kultury i struktury organizacyjnej. Model kompetencji definiuje wzorcowe standardy zachowania w pracy, które należy zastosować $\mathrm{w}$ procedurach i narzędziach pozyskiwania, oceny rozwoju i motywowania pracowników (Jabłońska-Wołoszyn, 2016, s. 134).

Nie ulega wątpliwości, że dorobek naukowy dotyczący wykorzystania kompetencji w resorcie obrony narodowej stale się powiększa, ponieważ to właśnie aspekty "miękkie” stają się wyznacznikiem sprawności działania Sił Zbrojnych (SZ). Ewolucja działania w organizacjach publicznych od administrowania do zarządzania publicznego, gdzie kompetencje mają ważny udział, dotyczy również organizacji wojskowych (Nowakowska-Krystman, Piotrowska-Trybull, 2016). Wojsko działa w otoczeniu, które również tak jak otoczenie organizacji biznesowych charakteryzuje się zmiennością,
Przegląd Organizacji, Nr 2 (949), 2019, ss. 37-43 www.przegladorganizacji.pl @Towarzystwo Naukowe Organizacji i Kierownictwa (TNOiK) złożonością i dynamiką (Trochowska, 2016, s. 17-39). Zatem wszelkie rekomendacje dotyczące modyfikacji procesów zarządzania, a takim jest kształtowanie zachowań pracowników w oparciu o najlepsze praktyki zarządzania kompetencjami, są ważnym głosem w rozwoju Sił Zbrojnych.

Znaczenie kompetencji żołnierzy jako czynnika przewagi niematerialnej $\mathrm{w}$ działaniach wojskowych podkreśla T. Majewski (2012, s. 98), twierdząc, że „tworzenie przewagi niematerialnej $\mathrm{w}$ obszarze kompetencji polega na:

- doborze na stanowiska służbowe kompetentnych żołnierzy zawodowych o kompetencjach zbliżonych do pożądanych lub potencjale rozwojowym pozwalającym stosunkowo szybko nabyć nowe kompetencje, - stworzeniu warunków doskonalenia kompetencji,

- pełnym wykorzystaniu kompetencji kadry dowódczej podczas działań”.

Szczególną grupą w wojsku, której kompetencje w bezpośredni sposób wpływają na skuteczność działań sił zbrojnych, są dowódcy. Podobnie jak w przypadku kompetencji menedżerów w organizacjach biznesowych, identyfikacja kompetencji dowódców stanowi źródło wielu badań i opracowań (Majewski, 2013; Predel, 2015; Łydka, 2015). Wśród wielu pozycji brakuje jednak badań na temat praktyki wykorzystania kompetencji w wojsku - szczególnie w zakresie 
realizacji procesu personalnego. Jeśli przyjmiemy, iż podstawą podejścia opartego na kompetencjach jest zdefiniowanie pożądanych dla organizacji zachowań charakteryzujących najwyższej klasy wykonawcę, to ich wykorzystanie powinno być widoczne w procedurach i narzędziach zarządzania ludźmi w Siłach Zbrojnych (Jabłońska-Wołoszyn, 2012, s. 204). Przyjmując, iż organizacje definiują kryteria kompetencyjne, tworzą modele kompetencji, a następnie wykorzystują je do budowy narzędzi zarządzania zasobami ludzkimi, przedmiotem badań jest praktyka kształtowania zachowania żołnierzy za pomocą kryteriów kompetencyjnych. Celem badania, którego wyniki prezentowane są $\mathrm{w}$ artykule, jest ocena sposobu, w jaki potencjał kompetencyjny wojska przejawia się na poziomie:

- proceduralnym - wykorzystanie kompetencji w formalnym procesie personalnym,

- podmiotowym - realizacja praktyki zarządzania kompetencjami poprzez modelowanie kompetencji żołnierzy w ramach procesu kadrowego.

Konsekwencją badania i analizy wyników jest przedstawienie rekomendacji do wykorzystania kompetencji do zarządzania zasobami ludzkimi w organizacji wojskowej.

\section{Opis badania}

$\mathbf{R}$ ealizacja postawionego celu wymagała przestudiowania formalnych dokumentów regulujących proces personalny $\mathrm{w}$ wojsku oraz przeprowadzenia badania empirycznego. W trakcie pracy wykorzystano:

1) analizę krytyczno-poznawczą regulacji dotyczących zarządzania zasobami ludzkimi w Siłach Zbrojnych. Źródła wtórne miały charakter formalnoprawny, a ich analiza została wykonana wspólnie z praktykiem, doktorantką zatrudnioną w jednostce wojskowej,

2) badanie o charakterze pilotażowym $\mathrm{z}$ wykorzystaniem metody kwestionariusza. Analizę danych przeprowadzono z wykorzystaniem arkusza Excel.

Celem badania była ocena realizacji procesu personalnego $\mathrm{z}$ perspektywy beneficjenta, jakim jest kadra oficerska wojska. Pytania w kwestionariuszu zostały pogrupowane $\mathrm{w}$ zagadnienia odzwierciedlające podejście oparte na kompetencjach w zakresie:

- powiązania zarządzania ludźmi ze strategią organizacji, indywidualną rolą pracownika w realizacji celów i praktyczną realizacją procesu personalnego,

- rozwoju kompetencji zawodowych, wykorzystania informacji zwrotnej do rozwoju kompetencji i wyzwań organizacji.

Badanie przeprowadzono w 2017 r. w ramach pracy naukowo-badawczej „Potencjał kompetencyjny Sił Zbrojnych RP” na grupie 101 oficerów uczestniczących w różnych formach szkolenia oraz kształcenia w Akademii Sztuki Wojennej (tab. 1). Wśród respondentów były 2 kobiety, 93 mężczyzn, natomiast 6 osób biorących udział w badaniu nie zaznaczyło odpowiedzi. Fakt ten, mimo deklaracji ze strony zespołu badawczego o zapewnieniu anonimowości uczestnikom badania, może wskazywać na ich obawy o możliwość identyfikacji ich tożsamości.

Tabela 1. Respondenci uczestniczący w badaniu według ptci

\begin{tabular}{|c|c|c|}
\hline Respondenci & $\begin{array}{c}\text { Liczba } \\
\text { respondentów }\end{array}$ & \% respondentów \\
\hline kobiety & 2 & 2 \\
\hline mężczyźni & 93 & 92 \\
\hline braki & 6 & 6 \\
\hline ogółem & 101 & 100 \\
\hline
\end{tabular}

Źródło: opracowanie wtasne

W badaniu przeprowadzonym w ASzWoj nie było żołnierzy, których staż służby wynosiłby mniej niż 4 lata, 1 osoba zadeklarowała, że jej staż mieści się w przedziale od 5 do 8 lat, natomiast największy udział w badanej grupie stanowili żołnierze, których staż wyniósł powyżej 16 lat (83\%). Spośród osób uczestniczących w badaniu 77 osób (76\%) zajmowało stanowiska dowódcze. Jedna osoba nie podała informacji dotyczącej zajmowanego stanowiska.

\section{Kompetencje a realizacja procesu personalnego w wojsku - dyskusja stanu obecnego}

D okumentem formalnym, który reguluje realizację procesu personalnego $\mathrm{w}$ wojsku jest Ustawa $\mathrm{z}$ dnia 11 września 2003 r. o służbie wojskowej żołnierzy zawodowych (Dz.U. z dnia 11.09.2003). W dokumencie tym znajdują się wytyczne dotyczące: zatrudnienia, powołania do zawodowej służby wojskowej, standardów kwalifikacyjnych na poszczególnych stanowiskach, ścieżki rozwoju, wynagradzania i zwalniania.

Wśród poszczególnych procedur personalnych znajduje się tylko jeden przykład wykorzystania kompetencji, którym jest ocena okresowa. Corocznemu opiniowaniu służbowemu, które jest realizowane w okresie od dnia 15 sierpnia do dnia 15 października, podlegają wszyscy żołnierze zawodowi (Dz.U. z dnia 11.09.2003, art. 26). „Opiniowanie służbowe żołnierza zawodowego ma: ocenić jego wywiązywanie się z obowiązków na stanowisku służbowym; oceniać jego kompetencje i predyspozycje; wyznaczać kierunki rozwoju zawodowego i określać potrzeby szkoleniowe opiniowanego żołnierza. Opinię służbową sporządza osobiście bezpośredni przełożony żołnierza zawodowego. Przy ocenie predyspozycji przełożony sporządzający tę opinię może zasięgnąć opinii psychologa jednostki wojskowej" (Dz.U. z dnia 11.09.2003, art. 26).

Zgodnie $\mathrm{z}$ Rozporządzeniem Ministra Obrony Narodowej z dnia 26 maja 2014 r. w sprawie opiniowania służbowego żołnierzy zawodowych (Dz.U. z dnia 9 czerwca 2014 r.), oceniane są następujące kryteria, które mają zdecydowanie atrybuty kryteriów kompetencyjnych: 
1. wywiązywanie się opiniowanego z obowiązków służbowych na stanowisku służbowym lub zadań służbowych w przypadku opiniowanego pełniącego służbę w rezerwie kadrowej - według następujących kryteriów:

- jakość i terminowość wykonywania obowiązków lub zadań,

- dyspozycyjność,

- samodzielność i inicjatywa,

- planowanie i organizacja pracy;

2. odpowiedzialność,

3. determinacja w dążeniu do celu,

4. trafność i szybkość podejmowania decyzji,

5. odporność na stres,

6. komunikatywność i umiejętność pracy w zespole,

7. stosowanie się do przepisów, norm i reguł,

8. rozwój własny i podnoszenie kwalifikacji,

9. dbałość o sprzęt i mienie,

10. kultura osobista i dbałość o wygląd zewnętrzny.

Jak wynika z powyższego, polityka personalna resortu obrony narodowej precyzuje bardzo szczegółowo twarde zarządzanie zasobami ludzkimi: proces personalny i zasady jego realizacji. Jednak wprowadzenie jednego zestawu kompetencji dla wszystkich żołnierzy, który jest wykorzystany tylko do procesu opiniowania, stawia wiele znaków zapytania dotyczących prawidłowości zarządzania zasobami ludzkimi w wojsku.

Po pierwsze, w przypadku samego pozyskiwania żołnierzy do służby zawodowej, na wstępnym etapie selekcji nie bierze się pod uwagę aspektów posiadania predyspozycji, które powinien posiadać żołnierz. Bada się tylko profil kandydata pod względem psychologicznym i fizycznym, natomiast ustawa nie reguluje weryfikacji pod kątem posiadania kompetencji - standardów behawioralnych. Brak zdefiniowanych kompetencji minimalnych (progowych) do pełnienia służby w wojsku może prowadzić do ryzyka w sytuacjach kryzysowych, zarówno w czasie pokoju, jak i wojny. W przypadku wymagań kwalifikacyjnych przy powoływaniu żołnierzy do służby zawodowej, oprócz posiadanego przez kandydatów wykształcenia, a także udokumentowanych osiągnięć w zakresie dotychczas odbywanej służby, nie są brane pod uwage żadne inne kryteria, obrazujące posiadane kompetencje i potencjał do ich dalszego rozwoju. Tak więc w procesie pozyskiwania kadr do wojska powinno się przemodelować standard naboru o wprowadzenie progowych kryteriów kompetencyjnych i metod ich diagnozy w jednostkach decydujących o zatrudnianiu żołnierzy.

Po drugie, w systemie opiniowania brak jest podziału na kompetencje podstawowe i dowódcze, co - zdaniem autorki - jest niezgodne $\mathrm{z}$ założeniami modelu kompetencji i stanowi bardzo dużą wadę tego procesu. Zdaniem autorki, należy zdefiniować i wprowadzić do karty opisu stanowiska dowódcy wymagania kompetencyjne, które powinny odzwierciedlać poziom rozwoju kompetencji dowódczych na trzech poziomach: podoficerskim, oficerskim-taktycznym; oficerskim-strategicznym. Wprowadzenie do procesu personalnego w wojsku formalnych kompetencji dowódczych może spowodować rozwój metod opiniowania, jak również metod szkolenia na kursach dowódczych prowadzonych w jednostkach kształcenia wojska.

\section{Wyniki badań}

\section{Perspektywa strategiczna kształtowania kompetencji oficerów}

W kwestionariuszu zadano pytania dotyczące świadomości celów stawianych przed SZ w perspektywie strategicznej i operacyjnej, zgodnie z założeniem modelu kompetencji, który jest łącznikiem pomiędzy strategią organizacji a strategią zarządzania zasobami ludzkimi. Na rysunkach 1-4 przedstawiono odpowiedzi respondentów w wyżej wymienionym zakresie.

Przedstawione wyniki pokazują, że badani poddani w większości twardym i proceduralnym regulacjom (ustawy, rozporządzenia, procedury), w niewielkim lub co najwyżej średnim stopniu mają świadomość na temat celów stawianych Siłom Zbrojnym.

Wyżej oceniono świadomość w zakresie celów stawianych przed jednostką, w której służą badani. Jest to spowodowane przekazywaniem głównie mierzalnych celów krótkookresowych, ujętych w rozkazach.

Jeśli chodzi o znajomość i świadomość strategii ZZL, jest ona bardzo niewielka. Powodem tego stanu rzeczy może być brak permanentnego doskonalenia zawodowego w zakresie tzw. zarządzania miękkiego. Badani znają tylko swoje cele, bo tylko $\mathrm{z}$ nich są rozliczani. Brak jest im umiejętności myślenia ogólnego i długookresowego.

Z powyższego wynika, że narzędzia ZZL nie są stosowane i wiele jest w tym zakresie do poprawienia.

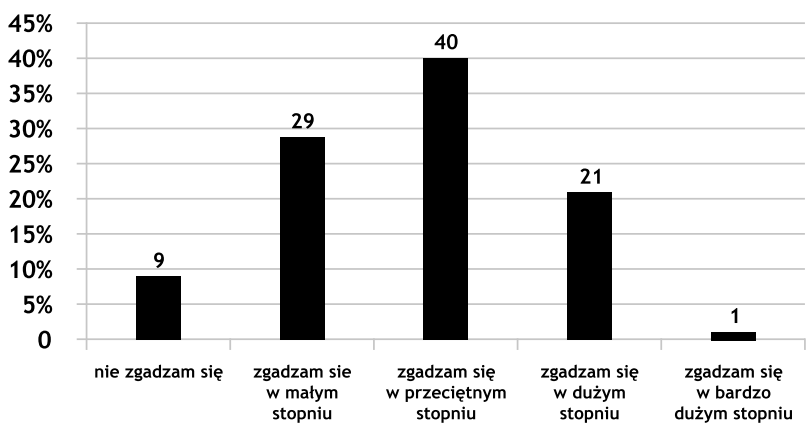

Rys. 1. Żotnierze znają najważniejsze cele stawiane Sitom Zbrojnym w Polsce

Źródto: opracowanie wtasne

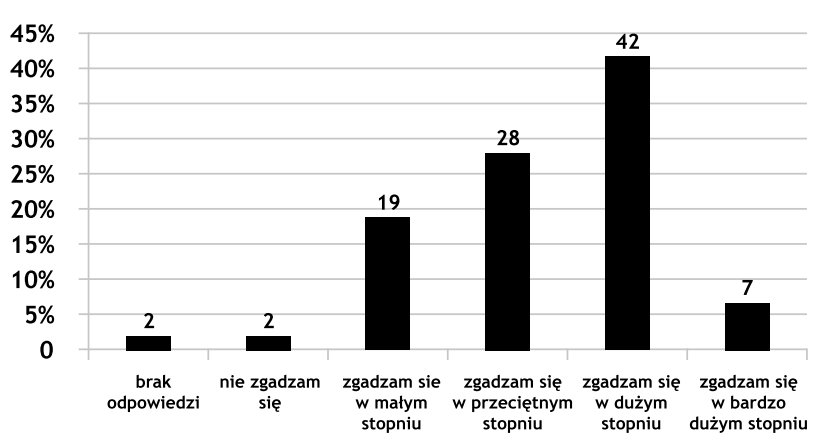

Rys. 2. Żołnierze znają cele i zadania, jakie realizuje jednostka, w której stużą

Źródto: opracowanie wtasne 


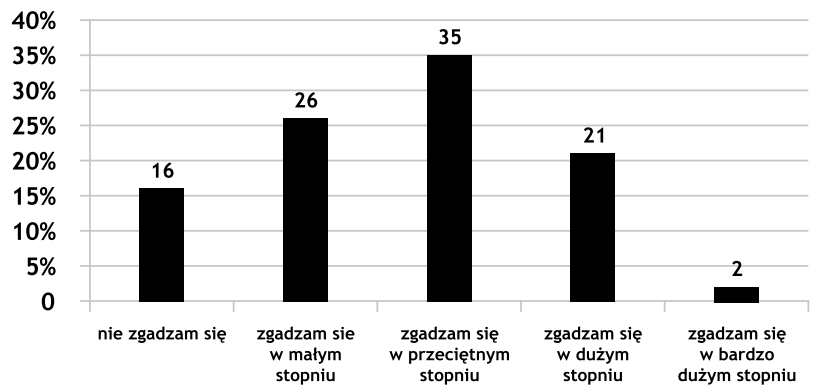

Rys. 3. W jednostce jest realizowana strategia zarządzania ludźmi

Źródło: opracowanie własne

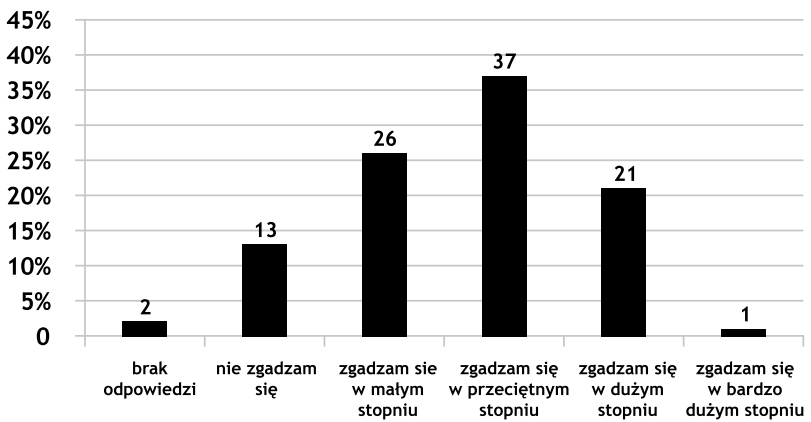

Rys. 4. Wojsko wykorzystuje nowoczesne narzędzia i techniki do zarządzania ludźmi

Źródło: opracowanie własne

\section{Świadomość roli oficera w realizacji celów Sit Zbrojnych}

W kwestionariuszu zadano pytania dotyczące świadomości roli, jaką pełnią respondenci w realizacji celów resortu obrony narodowej jako podstawy do świadomego kształtowania zachowań na stanowisku zgodnie z oczekiwaniami organizacji (rys. 5 i 6).

O ile żołnierze znają własne zakresy obowiązków i swoje indywidualne cele stawiane przez przełożonych, o tyle w zakresie kompetencji dotyczących np. wiedzy i posiadanych umiejętności nie są zorientowani. Wynika to głównie z charakteru i stylu zarządzania w miejscu pracy.

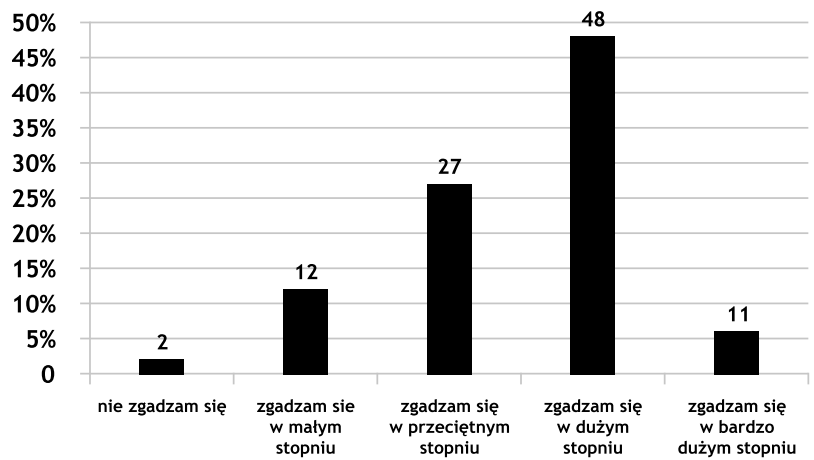

Rys. 5. Żotnierze znają prawa i obowiązki przypisane do stanowiska pracy

Źródło: opracowanie własne

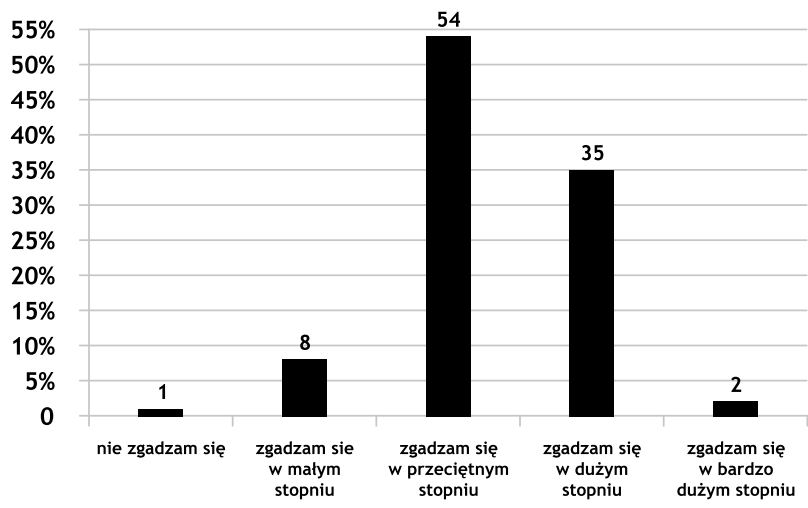

Rys. 6. Żołnierze znają najważniejsze wymogi (wiedza, umiejętności i postawy) stawiane im na poszczególnych stanowiskach w jednostce

Źródło: opracowanie własne

\section{Praktyczna realizacja procesu zarządzania zasobami ludzkimi w Sił Zbrojnych}

W kwestionariuszu zadano pytania dotyczące świadomości realizacji procesu personalnego w SZ jako podstawy do kształtowania zachowań żołnierzy. Odpowiedzi na pytania prezentują rysunki 7-10.

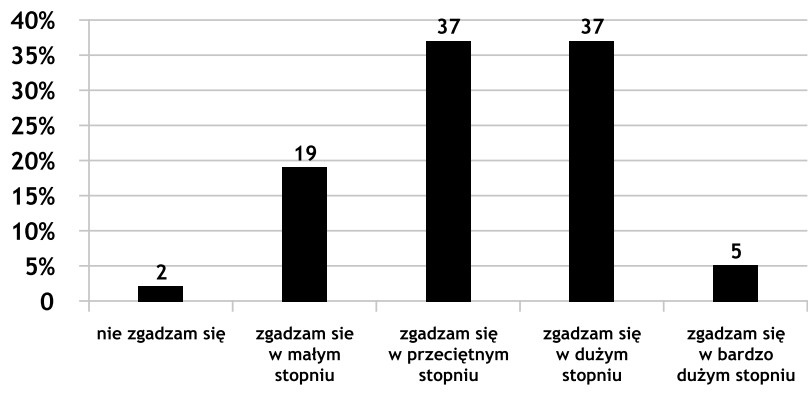

Rys. 7. Żotnierze znają formalne zasady zatrudniania, rozwoju i oceny w jednostce, w której stużą

Źródło: opracowanie własne

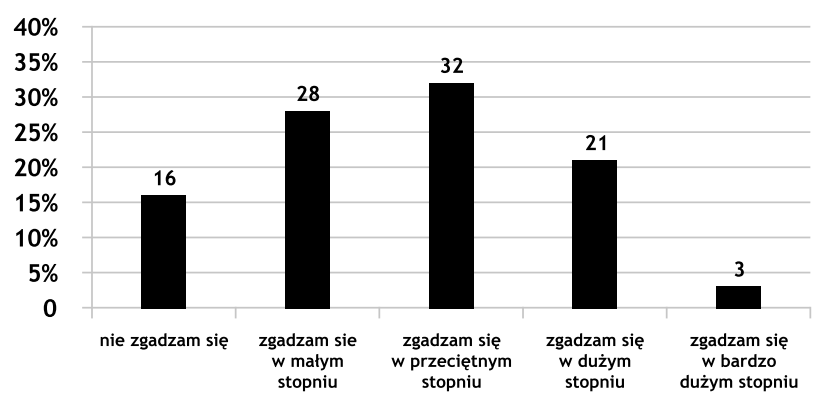

Rys. 8. W trakcie naboru do jednostki wiedza, umiejętności i postawy kandydatów są rzeczywiście weryfikowane przez komisję rekrutacyjną

Źródło: opracowanie własne

Ze względu na istnienie jasnych, formalnych uwarunkowań pozyskiwania kadr, pracownicy rozpoznają zasady naboru i zatrudnienia. Nie jest to jednak spójne ze znajomością oceny wyników weryfikowanych przez powołane komisje weryfikacyjne. 
Poza tym okresowa ocena pracy, wykonywana przez przełożonego nie jest zdaniem badanych obiektywna, ponieważ nie odnosi się do posiadanych przez pracowników kompetencji oraz umiejętności, co może powodować, iż jest nieobiektywna. Pomimo tego jednak istnieje u badanych dość duża świadomość możliwości negocjowania oceny i odniesienia się do niej.

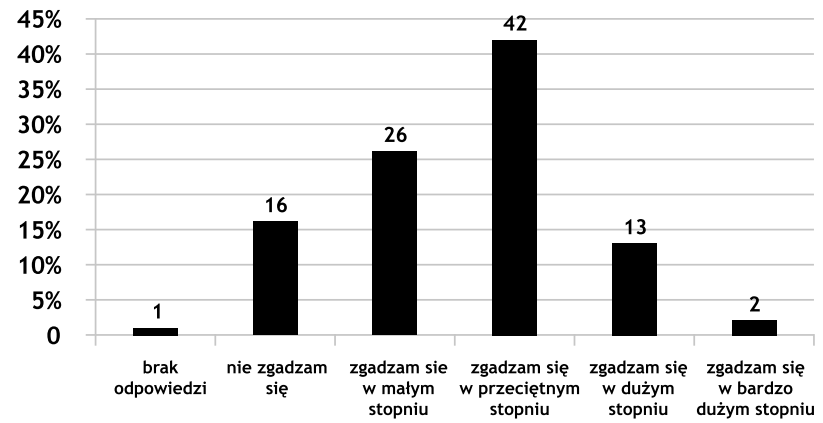

Rys. 9. Formalna ocena (opiniowanie) pokazuje rzeczywisty poziom wiedzy, umiejętności i postaw żołnierzy jednostki Źródto: opracowanie własne

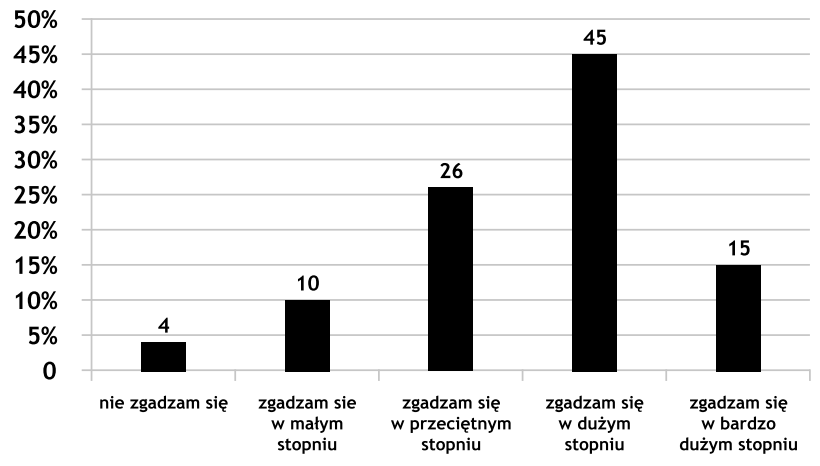

Rys. 10. Żołnierz ma możliwość odniesienia się do wyniku oceny stużbowej

Źródto: opracowanie wtasne

\section{Kształtowanie kompetencji a informacja zwrotna}

W kwestionariuszu zadano pytania dotyczące kształtowania zachowań pracowników SZ za pomocą informacji zwrotnej, podstawowego narzędzia wykorzystywanego do rozwoju kompetencji w organizacjach publicznych i biznesowych (rys. 11-13).

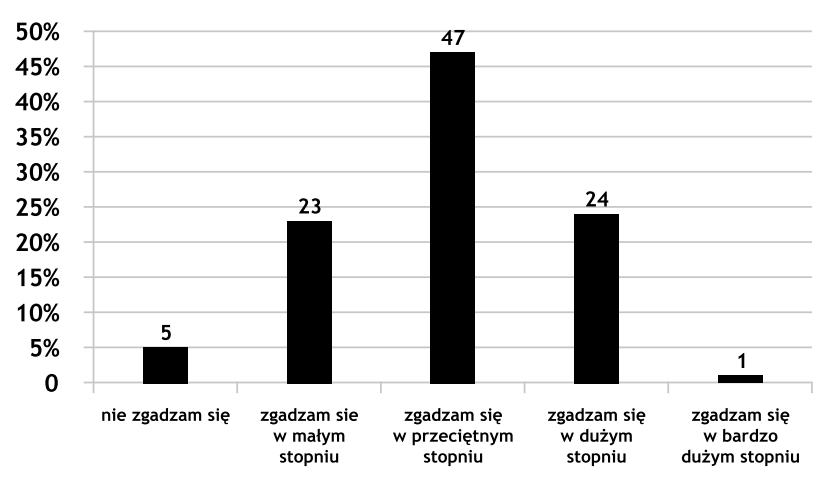

Rys. 11. W trakcie bieżącej realizacji zadań przełożony przekazuje informację zwrotną dotyczącą poziomu wiedzy, umiejętności i sposobu zachowania podwtadnych Źródto: opracowanie własne

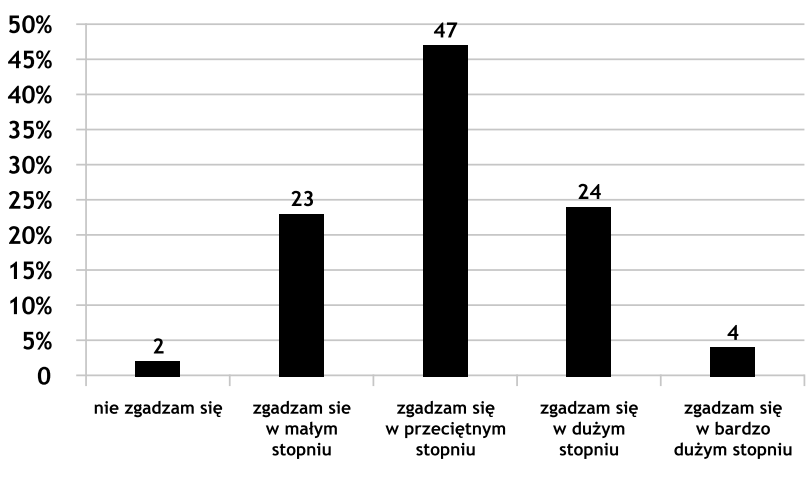

Rys. 12. W trakcie bieżącej realizacji zadań przełożony zachęca do dzielenia się wiedzą przez podlegtych pracowników Źródto: opracowanie wtasne

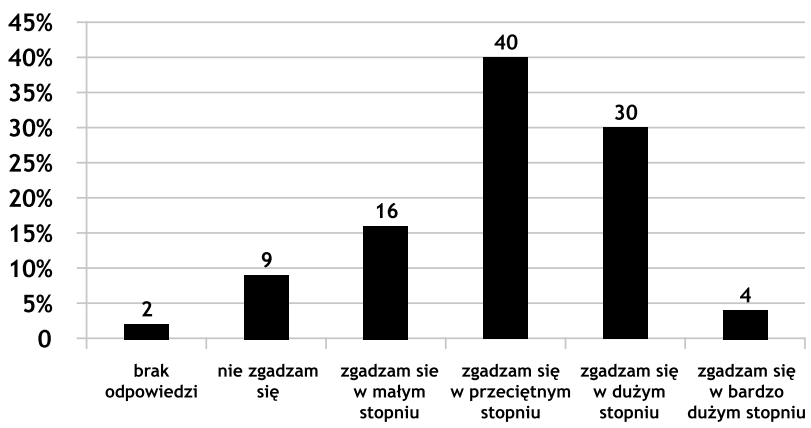

Rys. 13. Przełożony motywuje do zdobywania nowej wiedzy i doskonalenia umiejętności

Źródło: opracowanie wtasne

Ocena okresowa, a zwłaszcza informacja zwrotna przekazywana przez przełożonego nie skutkuje motywacją do zdobywania dalszej wiedzy zawodowej w wojsku. Dzielenie się wiedzą nie jest zachowaniem promowanym w wojsku - wynikiem tego może być jej zbytnie sformalizowanie i traktowanie konieczności uczenia innych jako przykrego obowiązku.

\section{Rozwój kompetencji w praktyce wojskowej}

W kwestionariuszu zadano pytania dotyczące realizacji działań w SZ doskonalących kompetencje, jako podstawy do oceny procesu rozwoju zgodnie z założeniami modelu kompetencji. Odpowiedzi na pytania prezentują rysunki 14-17.

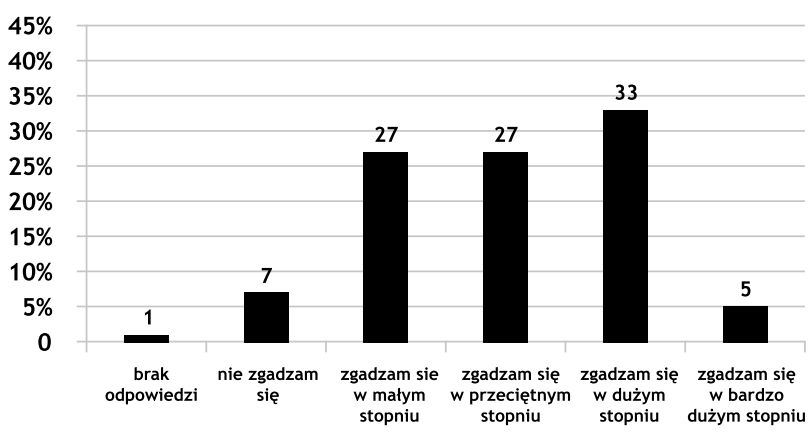

Rys. 14. Jednostka daje możliwość rozwoju kariery zawodowej tym, którzy posiadają wysokie kompetencje Źródto: opracowanie wtasne 


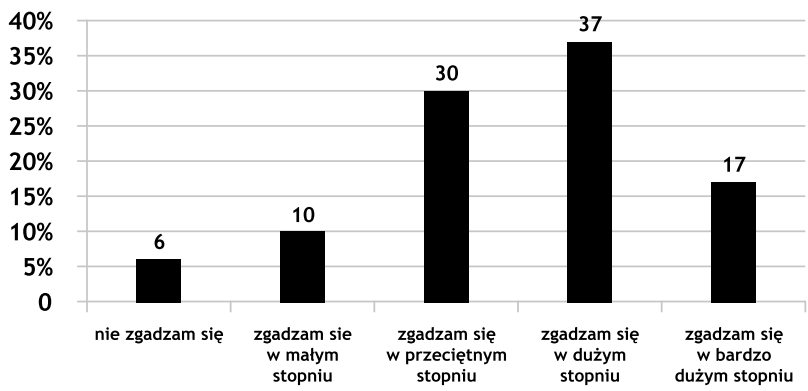

Rys. 15. Dobre relacje w jednostce umożliwiają rozwój kompetencji zawodowych

Źródło: opracowanie wtasne

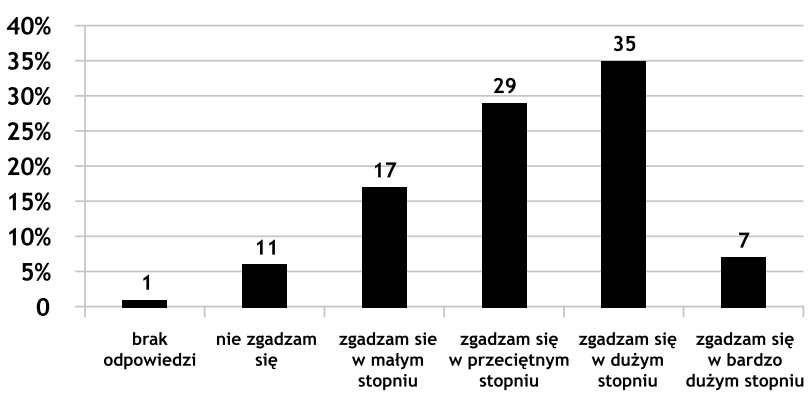

Rys. 16. Wysyłając żołnierza na szkolenie, przełożeni biorą pod uwagę potrzeby wynikające $z$ zadań realizowanych $w$ jednostce Źródto: opracowanie wtasne

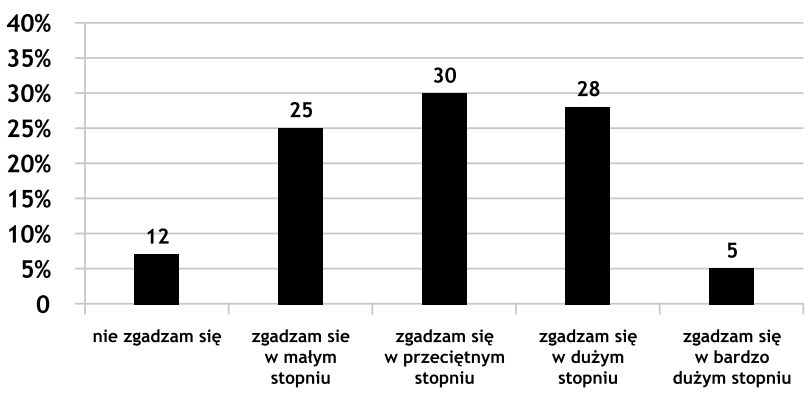

Rys. 17. Wysyłając żołnierza na szkolenie, przełożeni biorą pod uwagę jego aspiracje zawodowe

Źródto: opracowanie wtasne

Według badanych, posiadanie wysokich kompetencji zawodowych sprzyja rozwojowi kariery zawodowej. Rozwój kompetencji żołnierzy, doskonalenie zawodowe i szkolenia są realizowane równolegle z przydzielaniem zadań i obowiązków. Rozwojowi sprzyjają niewątpliwie również dobre relacje $\mathrm{z}$ pracownikami i przełożonymi $\mathrm{w}$ miejscu pracy - pod tym względem istnieje tutaj spójność.

Jednak, jak pokazuje badanie, wojsko nie zawsze bierze pod uwagę indywidualne potrzeby rozwojowe i szkoleniowe żołnierzy. Niepokojący jest również fakt rozbieżności posiadanych kompetencji z zajmowanym stanowiskiem przez oficerów.

\section{Kompetencja a praca zespołowa}

W kwestionariuszu zadano pytania dotyczące kształtowania zachowań zespołowych oraz budowania zespołów zadaniowych jako podstawy do kształtowania kompetencji w SZ. Odpowiedzi respondentów zaprezentowano na rysunkach 18-20.
Wyniki badania pokazują, że pracownicy organizacji wojskowej posiadają spore obawy o wyrażanie własnych poglądów i własnego zdania w kwestiach realizacji postawionych przed nimi zadań. Jest to związane ze zbytnim sformalizowaniem procesów zarządzania i delegowania uprawnień. Podobnie kwestia ta ma się w aspekcie realizacji zadań w formie grupowej - dla zdecydowanej większości badanych praca zespołowa nie wiąże się z podniesieniem ogólnej efektywności w wykonywaniu zadań.

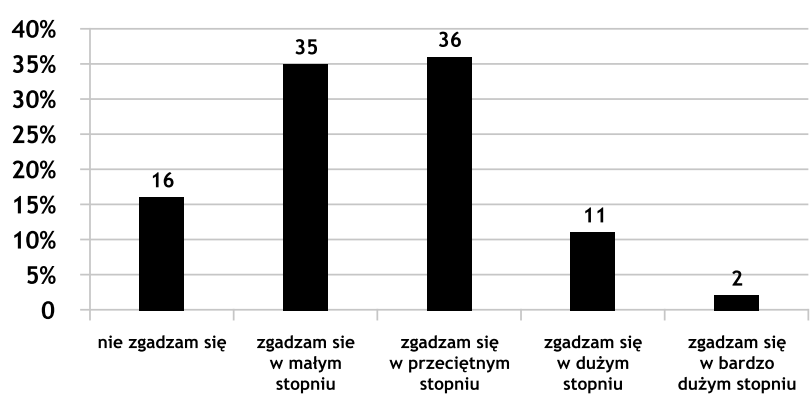

Rys. 18. Żołnierze nie mają obaw związanych z wyrażeniem własnego zdania na sprawy dotyczące wykonania zadania Źródto: opracowanie wtasne

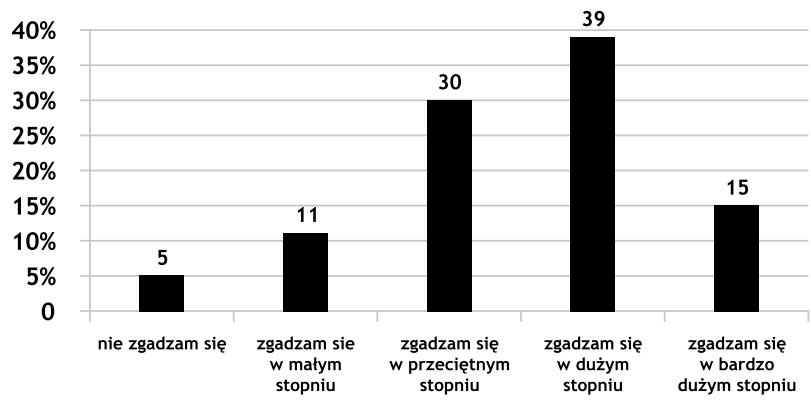

Rys. 19. Praca zespołowa w wojsku umożliwia rozwiązywanie ztożonych problemów

Źródto: opracowanie wtasne

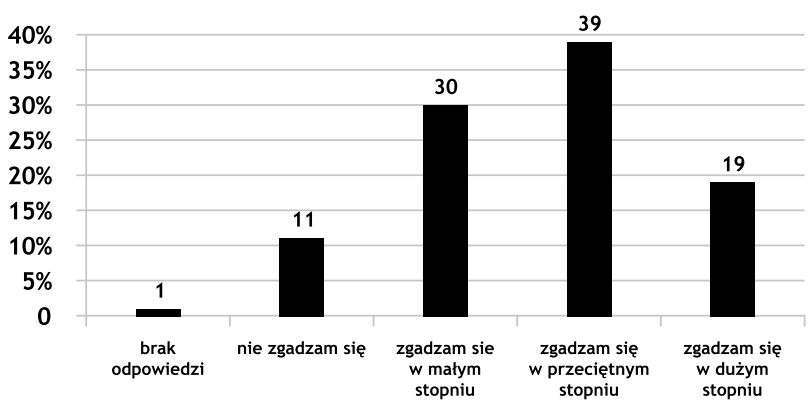

Rys. 20. Zespoty/sekcje tworzone w wojsku mają dużą samodzielność

Źródto: opracowanie wtasne

\section{Podsumowanie}

W praktyce organizacji warunkiem wdrożenia kompetencji w organizacji jest ich wykorzystanie w procesie oceny potencjału pracowników. Zarówno analiza procedur personalnych, jak i opinii oficerów pokazuje, iż świadome, oparte na jasnych zasadach kształtowanie kompetencji w SZ jest obszarem wyma- 
gającym zmiany. Podstawowym celem powinna być przebudowa funkcji personalnej i zaprojektowanie narzędzi do zarządzania ludźmi uwzględniających świadome kształtowanie kompetencji, promującej pracowników o wysokich kwalifikacjach i kompetencjach zbieżnych z modelem funkcjonowania SZ. Rekomendowane są $w$ tym zakresie rozwiązania sprawdzone w zarządzaniu kompetencjami:

- opracowanie modelu kompetencji w wojsku i jego wykorzystanie do modyfikacji narzędzi kadrowych: opisu stanowiska (KOSS) oraz formularza oceny okresowej (opiniowanie),

- włączenie do procesu pozyskiwania żołnierzy metod diagnozy kompetencji, takich jak np. wywiad kompetencyjny. Członkowie komisji kwalifikacyjnej powinni zadawać pytania sytuacyjne sprawdzające kompetencje (metoda STAR ${ }^{1}$ ) oraz wykorzystać zadania sytuacyjne (case study) w trakcie prowadzenia procesu selekcji kandydatów,

- włączenie do procesu oceny kandydatów na stanowiska dowódcze metody Assessment Centre/Development Centre oraz wykorzystanie do okresowej oceny kompetencji dowódczych narzędzi wykorzystywanych w biznesie, np. ocena $180^{\circ}$ lub $360^{\circ}$.

\section{dr Maria Jabłońska-Wołoszyn \\ Akademia Sztuki Wojennej \\ Wydział Zarządzania i Dowodzenia \\ ORCID: 0000-0001-8588-6899 \\ e-mail: m.wołoszyn@akademia.mil.pl}

\section{Przypis}

1) STAR polega na: zapytaniu kandydata o konkretną sytuację z przeszłości (S - sytuation), ustaleniu konkretnych zadań, jakie realizował i za które odpowiadał w przeszłości ( $\mathrm{T}$ - task), rozpoznaniu konkretnych działań (A - action) podejmowanych przez kandydata w celach realizacji tych zadań, samoocenie konkretnych rezultatów uzyskanych przez kandydata $(\mathrm{R}-$ result).

\section{Bibliografia}

[1] Dubois D., Rothwell W. (2008), Zarzadzanie zasobami ludzkimi oparte na kompetencjach, Helion, Gliwice.

[2] Jabłońska-Wołoszyn M. (2016) Elementy polityki personalnej a kultura organizacyjna, [w:] Ł. Sułkowski, M. Bednarek, A. Parkes (red.), Kulturowa zmienność systemów zarzadzania, Difin, Warszawa, s. 133-142.

[3] Jabłońska-Wołoszyn M. (2012), Aspekty wdrożeniowe wykorzystania kompetencji w ZZL, „Przedsiębiorczość i Zarządzanie”, Tom XIII, zeszyt 15, s. 199-213.

[4] Łydka W. (2015), Dysfunkcje $w$ doskonaleniu kompetencji przywódczych oficerów, [w:] Kompetencje społeczne $w$ kierowaniu i dowodzeniu Siłami Zbrojnymi. Teoria i praktyka, WCEO, Warszawa.

[5] Majewski T. (2012), Zarzadzanie kompetencjami, AON, Warszawa.
[6] Majewski T. (2013), Rozwój zawodowy kadr dowódczych $w$ Siłach Zbrojnych, Wydawnictwo Menadżerskie PTM, Warszawa.

[7] Nowakowska-Krystman A., Piotrowska-Trybull M., (2016), Przemiany $w$ Siłach Zbrojnych $w$ kontekście wspótczesnych koncepcji zarządzania, [w:] K. Krukowski, S. Sasak (red.), Tendencje we współczesnym zarzadzaniu publicznym, Studia i Monografie, Instytut Spraw Publicznych UJ, Kraków.

[8] Predel G. (2015), Korzystanie z kompetencji społecznych przez kadrę dowódcza Sił Zbrojnych RP, [w:] Kompetencje społeczne w kierowaniu i dowodzeniu Siłami Zbrojnymi. Teoria i praktyka, WCEO, Warszawa.

[9] Rozporządzenie Ministra Obrony Narodowej z dnia 26 maja 2014 r. w sprawie opiniowania służbowego żołnierzy zawodowych, Dz.U. z dnia 9 czerwca 2014 r.

[10] Sienkiewicz L. (red.), (2013), Zarządzanie zasobami ludzkimi w oparciu o kompetencje. Perspektywa uczenia się przez całe życie, IBE, Warszawa s. 68-71.

[11] Trochowska K. (2016), Kompetencje międzykulturowe dla bezpieczeństwa i obronności. Teoria i praktyka, AON, Warszawa, s. 17-39.

[12] Ustawa $z$ dnia 11 września 2003 r. o służbie wojskowej żołnierzy zawodowych, Dz.U. z dnia 11.09.2003 r.

\section{Use of Competences in the Process of Human Resources Management of Armed Forces in Poland}

\section{Summary}

The military is a public organisation, which like other organizations of this sector is subject to a trend of organisational and operational efficiency improvement. Recently the term "competence" has appeared here, which is not associated with military rank or permission level but with the standard behaviour - competency model - of soldiers reviewed. The aim of this study is to present a practical use of competences in the process of managing people in the military. In the empirical part, the HR process in the army has been evaluated in terms of using competence-based solutions in the army. The paper also presents the results of a survey conducted among officers, which covered the strategic perspective of shaping officers' competences, awareness of the officer's role in achieving the objectives of the Polish Armed Forces, practical implementation of human resources management in the army and the conditions for developing competences in practice The conclusions demonstrate a need for a greater use of competence management in the implementation of HR process in the Armed Forces.

\section{Keywords}

competence management, personal process, human resource management, Armed Forces 